\title{
Exploring Madrasah Students Mathematics Literacy Ability
}

\author{
M. Imamuddin ${ }^{1 *}$, Zulmuqim ${ }^{2)}$, Nana Sepriyanti ${ }^{3)}$ \\ ${ }^{1)}$ Mathematics Education, IAIN Bukittinggi \\ ${ }^{2)}$ Postgraduate Islamic Education, UIN Imam Bonjol Padang \\ ${ }^{3)}$ Mathematics Education, UIN Imam Bonjol Padang \\ *Coresponding Author \\ Email :
}

\begin{abstract}
This study aims to explore students' mathematics literacy ability and its contributing factors. This research was conducted at MTsN 2 Bukittinggi with 20 students of grade VIII as the subjects the study. The students were selected through random sampling. The instruments used in this research were test and interview. The based on the research results, information obtained: 1) Students are not used to working on questions that are different from the sample questions given by the teacher, 2) Students feel the problems used in the questions are more difficult than routine problems given by the teacher, 3) Students are accustomed and feel comfortable with the questions. which is applicable, and 4) Students are not familiar with the Islamic context used in the questions. The findings in this study reveal that students' Mathematics literacy ability is in the low category, and this low ability is caused by: 1) the problems given in mathematics learning tend to be the routine problems and 2) the students get accustomed to answering applicative questions and are not used to using them in contextual use (especially in Islamic context)
\end{abstract}

Keywords: Exploring, Mathematics Literacy Ability, Madrasah Students

\section{INTRODUCTION}

Freedom to learn (merdeka belajar) is an educational program launched in 2021 by the Indonesian government. One of the programs is that Indonesian students will be equipped with literacy ability. Literacy can be regarded as the ability to process information. Majid defines literacy as the ability to read, write, speak, count, and solve problems at the skill level required in work, family and society (Majid, 2012). In addition, Retnaningdyah et.al define literacy as the ability to access, understand, and use something intelligently through various activities including reading, seeing, listening, writing, and / or speaking (Retnaningdyah et al, 2016). Literacy ability allows individuals, families, and communities to improve their quality of life, (Isnaniah, et al., 2021). Furthermore, literacy has a multiplier effect such as eradicating poverty, reducing child mortality, curbing population growth, achieving gender equality, and ensuring sustainable development, peace and democracy (UNESCO, 2014). Therefore, it is highly necessary for Indonesian students to have it in order to develop themselves. The slogan Literacy for All proclaimed by UNESCO emphasizes that students should have literacy ability as the provision for them to live in the future (UNESCO, 2014).

One of the literacy ability that students need to have is mathematics literacy. Kusumah defines mathematics literacy as the required skills and knowledge to develop oneself socially, economically, and culturally in the modern life (Kusumah, 2011). Ojose defines mathematics literacy as the ability to understand and to use basic mathematics in everyday life (Ojose, 2011). Moreover, De Lang defines mathematics literacy as the ability not limited to performs a series of methods or procedures only but to have basic mathematical knowledge that enables a member of society to live in difficult situations and to achieve what they need (De Lang, 2007). 
In simpler terms, mathematics literacy can be defined as the ability to formulate, apply, and interpret mathematical symbols and to have skills and knowledge in using mathematics in everyday life. From the definitions of above, it is highly reasonable and important that every Indonesian student possess this literacy.

Regarding the importance of mathematics literacy for students, especially students of SMP / MTs in Bukittinggi, Rusdi conducted the research by analyzing the semester exam and school final exams for mathematics at SMP/ MTs in Bukittinggi. The results of his study indicated that (1) Mathematical problems tested to students were mostly about direct calculation with no context given, and (2) Mathematics literacy skills were at level 3 and thus classified as low (Rusdi, 2017). Furthermore, the research findings by Imamuddin and Musril revealed that students' ability on integrated mathematics literacy and the Quran in Madrasah Tsanawiyah was in the category of below level 1 (Imamuddin \& Musril, 2019). The research by Khairunnisa and Sepriyanti also indicated that the low literacy ability of madrasah students was caused by their unfamiliarity with the problems presented especially those required logical and applicable thinking (Khairunnisa \& Sepriyanti, 2019).

Regarding the low mathematics literacy skills of students, the researchers conducted a survey of one of the Madrasah Tsanawiyah Negeri in the Bukittinggi city, especially at MTsN 2 Bukittinggi. Based on the results of interviews with mathematics teachers and several madrasah students, it was found that students indicated that they had low mathematics literacy skills. The low mathematical literacy of the students of MTsN 2 Bukittinggi can also be seen when students work on math problems that relate to Islamic contexts.

Based on the above description, the researcher conducted research about students' mathematics literacy ability on mathematical problems, specifically related to the Islamic context. The Islamic context is integrated in learning mathematics to support the vision and mission of Islamic education and madrasah without neglecting the learning objectives (Imamuddin et al, 2020). Furthermore, madrasah students' mathematics literacy ability in terms of Islamic contexts in Bukittinggi needs to be explored in order to strengthen and enrich information on research findings related to mathematics literacy.

\section{RESEARCH METHODS}

This research is a descriptive study with the aims to explore students' mathematics literacy ability at MTsN 2 Bukittinggi. The research subjects consist of 20 students, who were randomly selectes from grade VIII. The test and interview were used to reveal students' mathematics literacy ability and its contributing factors. The test used was in the form of description using the Islamic context with 2 items. Before used in the research, the test was tested on other 15 students to see its level of validity and reliability.

The results of students' mathematics literacy test were analyzed based on 5 mathematics literacy ability from the most basic to the most complex ones: (1) The ability to identify problems to gather information needed to develop problem solving strategies, (2) The ability to represent mathematical problems using standard variables, symbols, diagrams and models, (3) The ability to choose and use problem solving strategies, (4) The ability to apply mathematical procedures to determine problem solutions, and (5) The ability to conclude problem solutions by making arguments based on the problems.

Furthermore, an interview was conducted with the students ( 3 students with low, medium, and high ability) and 1 teacher with the aim to identify, clarify, and uncover the causes of students' mathematics literacy ability or inability to solve the given problems 


\section{RESULTS AND DISCUSSION}

The first step in this research is to ensure that the test used is valid and reliable. For this reason, the test instrument containing 2 questions was first tested on 15 students who were not selected as research subjects. The test results are as follows: question number 1 is valid with high score criteria of 0.7033 , and question number 2 is also valid with high score criteria of 0.6637 . The results of test reliability is also with high criteria with a value of $r_{\text {table }} 0.361>(\alpha=$ 0.05). Thus, it can be concluded that the test can be used in research to analyze students' Mathematics literacy ability.

Furthermore, based on the test results, the data on students' mathematics literacy ability related to solving problems 1 and 2 are shown in Figures 1 and 2 below.

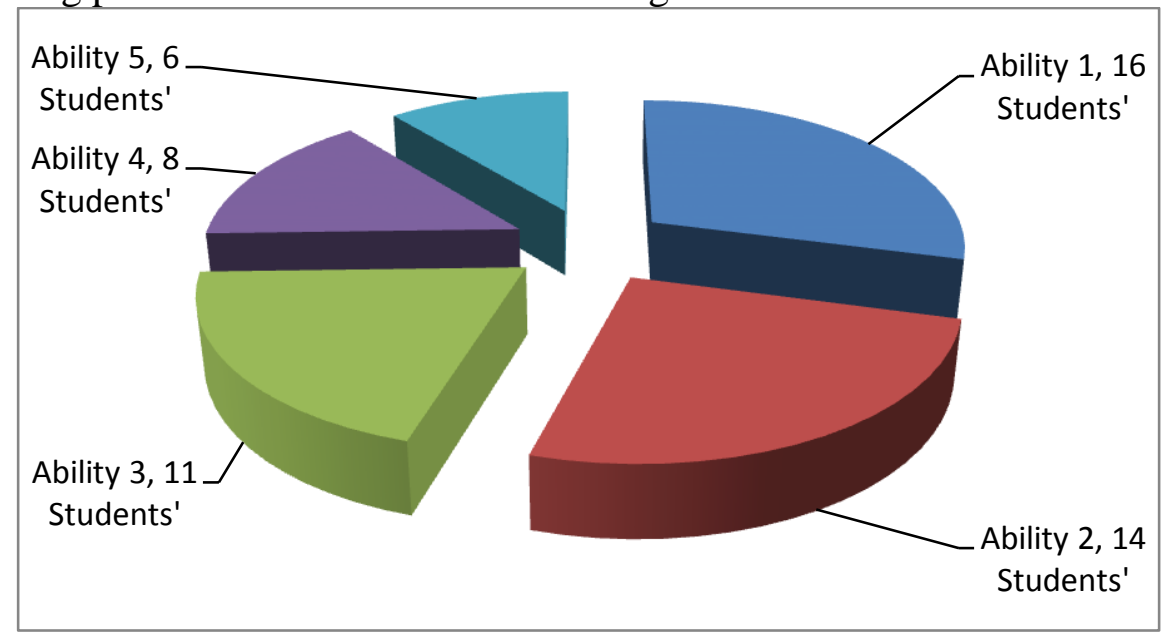

Figure 1. Students’ Mathematics Literacy Ability in Solving Problem 1

Based on Figure 1, students' mathematics ability in solving problem 1 is as follows: 16 students are able to collect information relevant to the problem for ability 1, and these students are able to represent mathematical problems using variables, symbols, diagrams, and standard models (ability 2). From 14 students, 11 of them are able to choose and use problem solving strategies properly (ability 3). From 11 students, 8 of them are able to apply mathematical procedures to determine problem solutions (ability 4). From 8 students, 6 of them are able to conclude problem solutions by making arguments based on the problem properly and correctly (ability 5). From this information, the number of students who are able to solve question number 1 correctly is 6 out of 20 students or $30 \%$ of the students.

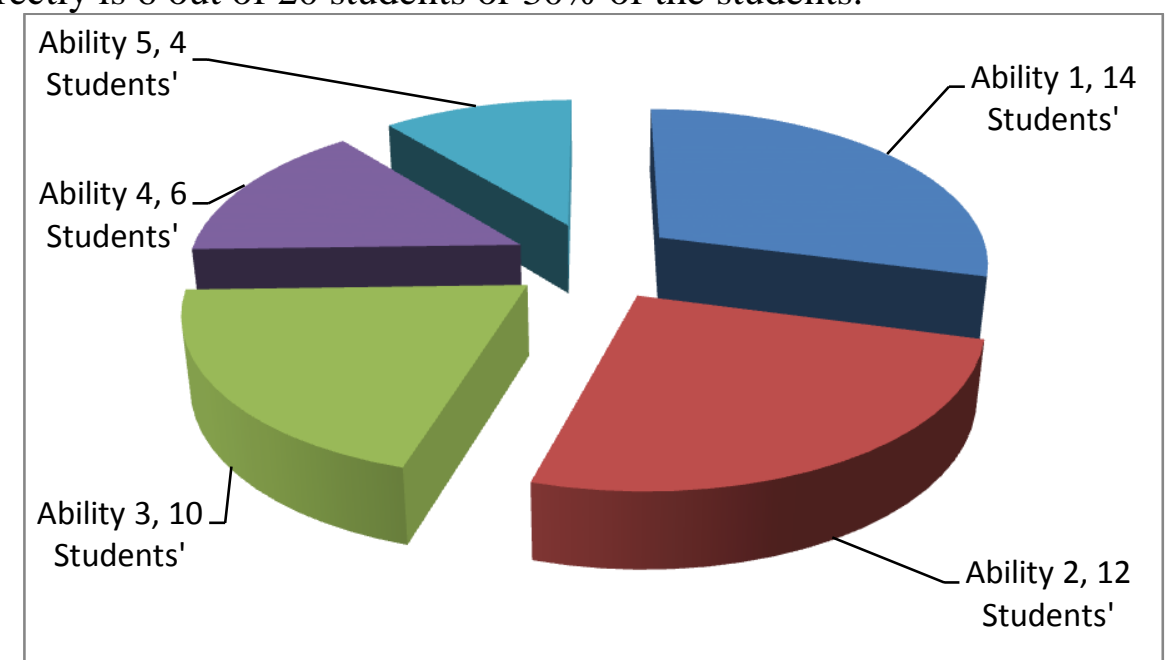

Figure 2. Students’ Mathematics Literacy Ability in Solving Problem 2 
Based on Figure 2, students' mathematics ability in solving problem 2 is as follows: 14 students are able to collect information relevant to the problem for ability 1 , and from 14 students, 12 of them are able to represent mathematical problems using variables, symbols, diagrams, and standard models (ability 2). For ability 3, 10 out of 12 students are able to choose and use problem solving strategies properly (ability 3). From 12 students, only 6 of them are able to apply mathematical procedures to determine problem solutions (ability 4). 6 out of 8 students are able to conclude problem solutions by making arguments based on the problem properly and correctly (ability 5). From this information, the number of students who are able to solve question number 2 correctly is 4 out of 20 students or $20 \%$ of the students.

From the obtained data, it can be said that students' mathematics literacy ability is in the low category. It is evident from the 20 students only $30 \%$ of them who are able to answer question number 1 properly and correctly, so the other rest are not able to apply their Mathematics literacy ability well. Meanwhile for question number 2, only 4 students or $20 \%$ of students are able to use their Mathematics literacy ability by giving correct answer.

Based on students' answers to problems 1 and 2, an interview was with students and teacher. The data from interview reveal that: 1) Students are not used to working on questions different from the examples given by the teacher, 2) Students feel the problems used in the questions are more difficult than the ones commonly given by the teacher, 3) Students are used to and feel comfortable with the amplicative questions, and 4) Students are not familiar with the Islamic context used in the questions.

The findings in this study indicate that students' mathematics literacy ability in Madrasah is in the low category. This low mathematics literacy ability is generally caused by: 1) the problems given in mathematics learning tend to be the routine problems and 2) the students get accustomed to answering applicative questions and are not familiar with using them in contextual use (especially in Islamic context). The findings of this study confirms those of previous studies, namely students have low ability in solving non-routine problems, (Rusdi, 2017; Pulungan, 2014), students are familiar with applied questions but not with the use of context (Imamuddin, 2020; Khairunnisa \& Sepriyanti, 2019; Rusdi, 2017).

\section{CONCLUSION}

Based on the research findings, it can be concluded that students' mathematics literacy ability in Madrasah is in the low category. This low mathematics literacy ability is generally caused by: 1) the problems given in mathematics learning tend to be the routine problems and 2) the students get accustomed to answering applicative questions and are not familiar with using them in contextual use (especially in Islamic context).

According to the researcher, the problems of madrasah students or Indonesian students in general related to their low mathematics literacy ability can be overcome by: 1). Giving math problems in mathematics learning by using context, 2). Familiarizing students with giving non-routine questions, and 3). Familiarizing students with problem solving and critical and creative thinking.

\section{REFERENCES}

De Lang, Jane (2007). Mathematics for Literacy, dalam Quantitative Literacy, Why Numeracy Matters for schools and Colleges, Proceding of the National Foum on Quantitative Literacy. Washington D.C.: National Academy of Sciences 
Imamuddin, M., \& Musril, H. A., (2019). Pengembangan Soal-soal Literasi Matematika Terintegrasi dengan Al-Quran di MTs N 2 Bukittinggi Tahun Pelajaran 2019/2020. IAIN Bukittinggi-BOPTN Penelitian Interdisiplinir 2019, tidak dipublikasikan

Imamuddin, M., Isnaniah, I., Zulmuqim, Z., Nurdin, S., \& Andryadi, A. (2020). Integrasi Pendidikan Matematika dan Pendidikan Islam (Menggagas Pembelajaran Matematika di Madrasah Ibtidaiyah). AR-RIAYAH: Jurnal Pendidikan Dasar, 4(2), 117-130.

Imamuddin, M. (2020, February). Students' Understanding of Mathematical Concepts Using Manipulative Learning Media in Elementary Schools. In Journal of Physics: Conference Series (Vol. 1471, No. 1, p. 012050). IOP Publishing.

Isnaniah, I., Imamuddin, M., Charles, C., Syahrul, S., \& Zulmuqim, Z. (2021). Kemampuan Literasi Matematika Siswa Berdasarkan Gender. Lattice Journal: Journal of Mathematics Education and Applied, 1(2), 131-137.

Khairunnisa \& Sepriyanti, N., (2019). Analisis Kemampuan Literasi Matematis Peserta Didik Di Kelas XI IPA 1 MAN 1 Padang Berdasarkan Kemampuan Matematika, Math Educa Journa: Jurnal Matemamatika dan Pendidikan Matematika, 3(1), 32-43

Kusumah, Y. S., (2011). Literasi Matematis. Prosiding Seminar Nasional Pendidikan MIPA. Pengembangan Pembelajaran MIPA Berorientasi Soft Skill Universitas. Bandar Lampung, 26 November 2011.

Majid, Abdul (2012). Belajar dan Pembelajaran: Pendidikan Agama Islam. Bandung: PT Remaja Rosdakarya

Ojose, Bobby (2011). Mathematics Literacy: Are We Able to Put The Mathematics We Learn Into Everyday Use? Journal of Mathematics Education, 4 (1), 89-100

Pulungan, D. A., (2014). Pengembangan Instrumen Tes Literasi Matematika. Jurnal of Educational Research and Evaluation. 3 (2), 74 - 78.

Retnaningdyah, P., Laksono, K., Mujiyem, Setyiorini, N. P., Sulastri, \& Hidayati, U. S., (2016). Gerakan Literasi Sekolah di Sekolah Menengah Pertama. Jakarta: Direktorat Jenderal Pendidikan Dasar dan Menengah Kementerian Pendidikan dan Kebudayaan

Rusdi (2017). The Challenge Of Mathematics Teacher In Globalization Era. Proceeding: ${ }^{2 n d}$ International Seminar on Education 2017 Empowering Local Wisdom on Education for Global Issue. Batusangkar, September 05 - 06 - 2017, 385 - 396

UNESCO, (2014). Literacy for All. http://en.unesco.org/themes/literacy-all. diakses 12 Januari 2021. 